\title{
Ecological Ordination and Distribution of Hygrophilous Species Growing on a Mediterranean Riverbank (SW Spain)
}

\author{
Francisco GÓMEZ MERCADO'*, Esther GIMÉNEZ LUQUE', Enrique LÓPEZ \\ CARRIQUE', Sergio DE HARO LOZANO², Fernando DEL MORAL TORRES² \\ ${ }^{1}$ Universidad de Almería. Campus de Excelencia Internacional Agroalimentario, CEIA3, Dpto. de Biología Vegetal \\ y Ecologia, Ctra. Sacramento s/n, E-04120 Almeria, Spain; frgomez@ual.es (*corresponding author) \\ ${ }^{2}$ Universidad de Almería. Campus de Excelencia Internacional Agroalimentario, CEIA3, Dpto. de \\ Edafologia y Quimica Agricola, Ctra. Sacramento s/n, E-04120 Almeria, Spain
}

\begin{abstract}
The Guadiamar riverbanks are home to riparian plant communities, such as alder, poplar and ash forests, tamujares, salt marshes, reed beds, etc. characteristic of Mediterranean rivers. A data set of these communities, including floristic relevés and environmental variables (physical and chemical soil properties, bioclimate) was analysed to correlate their floristic composition/species distribution with environmental variables. By means of an RDA (redundancy analysis) and a complementary cluster analysis four groups of species were discriminated according to their ecological requirements. The RDA displayed three major, parallel-running gradients (i.e., textural, bioclimatic and chemical) in environmental variables. Other less conspicuous, crossed gradients revealed the impact of man-made alterations, particularly in the middle reaches of the river. The results can be helpful in the planning of future ecologically oriented restoration programmes of wetlands.
\end{abstract}

Keywords: autoecology, green corridor, river Guadiamar, soil-plant relationships

\section{Introduction}

In the last decades wetlands have been widely recognized as ecologically valuable assets for a sustainable development strategy. Not only have they been extensively studied, but policies intended for their protection, preservation and efficient management have also been implemented (Montes del Olmo et al., 2007). However, only a few restoration or regeneration initiatives for these wetlands were successful (Mitsch and Gosselink, 2000). Most of the errors were the result of a lack of knowledge about the specific environmental conditions required by the organisms inhabiting these wetlands (Lee et al., 2005). There is no doubt that the success of these restoration projects is dependent on the available information about the ecologi$\mathrm{cal}$ interactions responsible for the succession of riparian vegetation (Glenz et al., 2006; Lu et al., 2006).

Therefore, it is necessary to assess the impact of environmental variables on these hygrophilous plant communities, detect which variables play a decisive role in the maintenance of the different communities and establish proper bioindicator species for each of them.

These ecological data will eventually be used to plan the most suitable management strategies for the restoration of these threatened ecosystems.

The number of studies on the autoecology of forest species increases daily and this research line has more and more supporters (Castillo et al., 2000; Konisky and Burdick, 2004; Navarro et al., 2006; Rubio et al., 1997, 2003; Thuiller et al., 2003). However, the available knowledge of many of the most frequent species of our plant heritage is still far from sufficient.

For correct planning of restoration plans it is interesting to use plant bioindicators, which will enable us to know the ecological conditions of the environment and choose in a proper way the species to be introduced. Studies on bioindicators are widely used in relation to different factors, such as pollutants (Klumpp and Klumpp, 1994; Zuccarini and Kampuš, 2011), water quality (Ceschin $e t$ al., 2010; Robach et al., 1996) soil quality (Böer, 1996; Galuszka, 2000; Migaszewski et al., 2001).

Given the shortage of studies on the response of riparian species to the different environmental variables, it is important to carry out a study to estimate as accurately as possible the tolerance shown by species to the different environmental factors that influence their biological dynamics and shape their distribution. For this purpose we first defined plant groups according to homogeneous response patterns to find out any possible relation with the ecological factors involved. Our final objective is to provide reliable information that could eventually lead to the use of these species as bioindicators in suitable, ecologically oriented restoration programmes. 
This research is one of the studies carried out to restore the Corridor Verde del Guadiamar (Seville), in the area affected by the accidental breach of the slag pond of the pyrite mine in Aznalcóllar in 1998 (Gómez Mercado et al., 2007, 2009, 2010, 2012).

\section{Material and methods}

\section{Study area}

The field work was carried out in the area of the "Corridor Verde del Guadiamar", a narrow strip of land 600 to $800 \mathrm{~m}$ wide and over $100 \mathrm{~km}$ long, encompassing $7900 \mathrm{ha}$. The strip is a long corridor connecting two large territories under protection, namely, the Parque Natural/Parque Nacional de Doñana and the Natural Parks of Aracena and Picos de Aroche and the Sierra Norte of Seville, in Andalusia, Spain (Fig. 1).

The territory presents a rich diversity of habitats. The upper third of the reaches of the river flows through the typical oak-studded pastureland ("dehesa") of Sierra Morena, often through deep rock-carved gullies, and substrates are usually metamorphic materials. The middle reaches of the river have long been traditional farming land, with terrains made up of gravels and sands of alluvial origin. The final stretch of the river enters a flood plain, territory where the dominant substrates are sands, silts and clays.

\section{Data collection}

Twenty-eight sites representing all types of vegetation found in the study area were selected. For each of these sites an identification sheet with the most relevant macromorphological information was completed with the corresponding data from a relevé of vascular plant species.

$10 \times 10 \mathrm{~m}$ square grids were chosen as sample plots. For each of them floristic relevés were carried out, and their species abundance-dominance was estimated by means of
Braun-Blanquet's scale (1964), subsequently modified, for statistical purposes, by van der Maarel (1979).

A soil sample was taken from each site, with a final equivalent volume of $3 \mathrm{dm}^{3}$, made up of five evenly distributed subsamples taken in the inventoried zone. Soil samples were taken at a depth of $30 \mathrm{~cm}$, regardless of the horizon sequence on the spot (Díaz-Maroto and VilaLameiro, 2008; Hagen-Thorn et al., 2004).

The soil samples were sieved through a $2 \mathrm{~mm}$ screen after removing any plant materials and roots. Particle size distribution was determined applying Robinson's pipette method (Soil Conservation Service 1972). Available water capacity was calculated by $\mathrm{AWC}=\mathrm{W}_{33}-\mathrm{W}_{1500}$ (Klute, 1986). $W_{33}$ and $W_{1500}$ refer to the gravimetric water content of a disturbed soil sample placed on a porous plate and equilibrated with an applied pressure of $33 \mathrm{kPa}$ and 1500 $\mathrm{kPa}$, respectively (Richards, 1954). Exchangeable bases and cation exchange capacity (CEC) were determined by the ammonium acetate $(\mathrm{pH}=7)$ method. $\mathrm{pH}$ was measured electrometrically in a 1:2.5 soil:water suspension and 1:2.5 soil: $\mathrm{KCl}$ solution ( $\mathrm{pH} \_\mathrm{KCl}$ ). Total $\mathrm{CaCO}_{3}$ was determined by the manometric method. Total organic carbon was determined by wet oxidation with potassium dichromate. Total nitrogen was determined by the Kjeldahl method (Bremmer, 1996). Bioavailable phosphorus was measured by the Olsen method (Olsen et al., 1954). Electrical conductivity and dissolved solids were measured on extracts of saturated soil-paste (Bartels, 1996).

The bioclimatic indexes (Io, Itc) were reckoned using the formula suggested by Rivas Martínez and Loidi (1999) and using the data from 36 meteorological stations located in the Guadiamar river basin and other neighbouring areas (data from the State Meteorological Agency, AEMET). From these data and by means of a regression analysis, estimated values for every site in the study area were obtained.
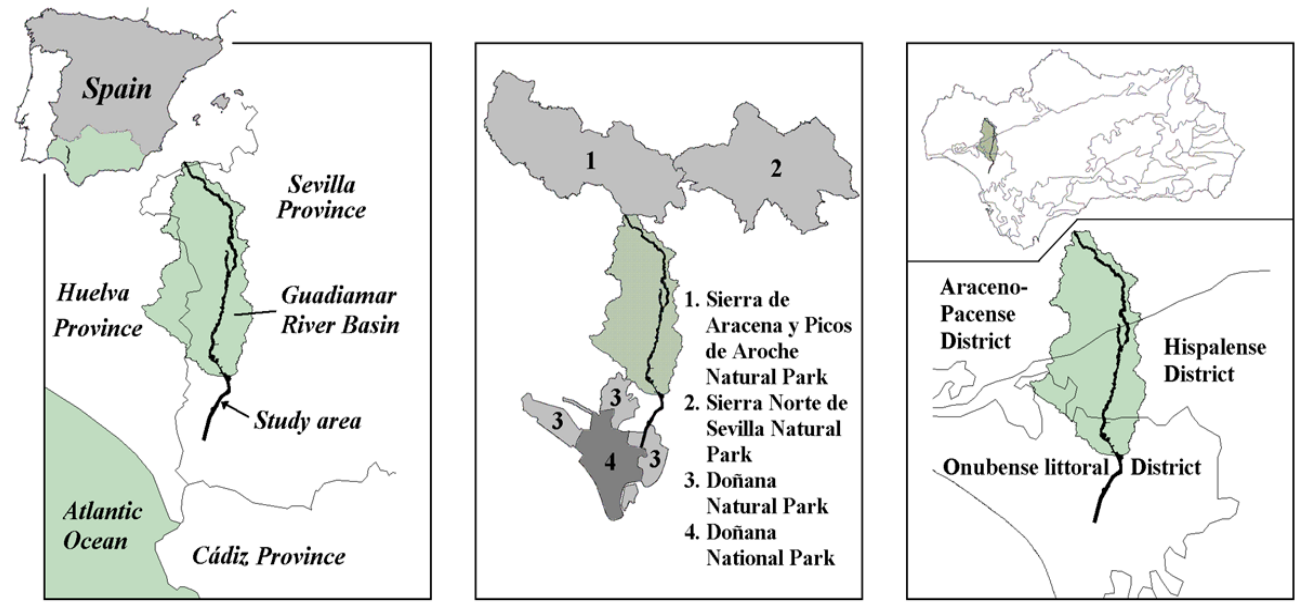

Fig. 1. Left: location of the area of study and the Guadiamar River Basin with regard to Spain, Andalusia and the provinces of Huelva, Seville and Cadiz. In the centre, a position between the protected spaces of Doñana and natural parks of Aracena and Picos de Aroche and Sierra Norte de Sevilla. On the right, situation on the biogeographical outline of Andalusia (Rivas Martinez et al., 1997) 
Tab. 1. Estimated environmental variables for each sample

\begin{tabular}{|c|c|c|c|c|c|c|c|c|c|c|}
\hline Label & Environmental variable & Unit & $\mathrm{F}$ & $\mathrm{P}$ & $\mathrm{A} / \mathrm{B}$ & $\mathrm{A} / \mathrm{C}$ & $\mathrm{A} / \mathrm{D}$ & $\mathrm{B} / \mathrm{C}$ & $\mathrm{B} / \mathrm{D}$ & $\mathrm{C} / \mathrm{D}$ \\
\hline $\mathrm{OC}$ & Total Organic Carbon & $\% \mathrm{w} / \mathrm{w}$ & 2.149 & 0.097 & & & & & & + \\
\hline CEC & Cation Exchange Capacity & $\mathrm{cmol}_{\mathrm{c}} \cdot \mathrm{kg}^{-1}$ & 122.080 & 0.000 & + & + & + & + & + & + \\
\hline $\mathrm{Ca}$ & Exchangeable Calcium & $\mathrm{cmol}_{\mathrm{c}} \cdot \mathrm{kg}^{-1}$ & 118.312 & 0.000 & + & + & + & + & + & \\
\hline $\mathrm{Mg}$ & Exchangeable Magnesium & $\mathrm{cmol}_{\mathrm{c}} \cdot \mathrm{kg}^{-1}$ & 317.657 & 0.000 & & + & + & + & + & \\
\hline $\mathrm{Na}$ & Exchangeable Sodium & $\mathrm{cmol}_{\mathrm{c}} \cdot \mathrm{kg}^{-1}$ & 35.103 & 0.000 & & + & + & + & + & + \\
\hline $\mathrm{K}$ & Exchangeable Potassium & $\mathrm{cmol}_{\mathrm{c}} \cdot \mathrm{kg}^{-1}$ & 400.297 & 0.000 & & + & + & + & + & + \\
\hline V & Base Saturation & $\%$ & 139.630 & 0.000 & + & + & + & + & + & \\
\hline $\mathrm{CO}_{3}$ & Total Carbonate & $\% \mathrm{w} / \mathrm{w}$ & 119.674 & 0.000 & + & + & + & + & + & + \\
\hline $\mathrm{N}$ & Total Nitrogen & $\% \mathrm{w} / \mathrm{w}$ & 8.400 & 0.000 & + & + & + & & + & \\
\hline $\mathrm{CN}$ & $\begin{array}{c}\mathrm{C} / \mathrm{N} \text { (Total Organic } \\
\text { Carbon/Total Nitrogen) }\end{array}$ & & 14.951 & 0.000 & & + & + & + & + & \\
\hline $\mathrm{P}$ & Bioavailable phosphorus & $\mathrm{mg} \cdot \mathrm{kg}^{-1}$ & 7.032 & 0.000 & & & + & & + & + \\
\hline Caex & Ca in saturation extract & $\mathrm{mmol} \cdot \mathrm{L}^{-1}$ & 23.307 & 0.000 & & + & + & + & + & + \\
\hline Mgex & $\mathrm{Mg}$ in saturation extract & $\mathrm{mmol}_{\mathrm{c}} \cdot \mathrm{L}^{-1}$ & 23.751 & 0.000 & & + & + & + & + & + \\
\hline Naex & $\mathrm{Na}$ in saturation extract & $\mathrm{mmol}_{\mathrm{c}} \cdot \mathrm{L}^{-1}$ & 29.215 & 0.000 & & + & + & + & + & + \\
\hline Kex & $\mathrm{K}$ in saturation extract & $\mathrm{mmol}_{\mathrm{c}} \cdot \mathrm{L}^{-1}$ & 43.443 & 0.000 & & + & + & + & + & + \\
\hline $\mathrm{CO}_{3} \mathrm{ex}$ & $\mathrm{CO}_{3}$ in saturation extract & $\mathrm{mmol}_{\mathrm{c}} \cdot \mathrm{L}^{-1}$ & 22.173 & 0.000 & & + & + & + & + & + \\
\hline $\mathrm{HCO}_{3} \mathrm{ex}$ & $\mathrm{HCO}_{3}$ in saturation extract & $\mathrm{mmol} \cdot \mathrm{L}^{-1}$ & 17.694 & 0.000 & & & + & & + & + \\
\hline H33 & Moisture content at $33 \mathrm{kPa}$ & $\% \mathrm{w} / \mathrm{w}$ & 230.643 & 0.000 & + & + & + & + & + & + \\
\hline $\mathrm{H} 1500$ & Moisture content al $1500 \mathrm{kPa}$ & $\% \mathrm{w} / \mathrm{w}$ & 210.396 & 0.000 & + & + & + & + & + & \\
\hline Hsat & Moisture content at saturation & $\% \mathrm{w} / \mathrm{w}$ & 59.100 & 0.000 & & + & + & + & + & + \\
\hline AWC & $\begin{array}{l}\text { Available Water Capacity: } \\
\text { AWC }=\mathrm{W}_{33}-\mathrm{W}_{1500}\end{array}$ & $\% \mathrm{w} / \mathrm{w}$ & 30.932 & 0.000 & + & + & + & + & + & \\
\hline Sand & Sand & $\% \mathrm{w} / \mathrm{w}$ & 389.549 & 0.000 & + & + & + & + & + & \\
\hline CS & Coarse Silt & $\% \mathrm{w} / \mathrm{w}$ & 38.830 & 0.000 & + & & + & + & + & \\
\hline FS & Fine Silt & $\% \mathrm{w} / \mathrm{w}$ & 247.344 & 0.000 & + & + & + & + & + & + \\
\hline Clay & Clay & $\% \mathrm{w} / \mathrm{w}$ & 647.962 & 0.000 & + & + & + & + & + & \\
\hline $\mathrm{pH}$ & $\mathrm{pH}$ & & 62.325 & 0.000 & + & + & + & + & + & \\
\hline pH_KCl & $\mathrm{KCl} \mathrm{pH}$ & & 115.709 & 0.000 & + & + & + & + & + & \\
\hline EC & Electrical Conductivity & $\mathrm{dS} \cdot \mathrm{m}^{-1}$ & 31.572 & 0.000 & & + & + & + & + & + \\
\hline Alt & Altitude & $\mathrm{m}$ & 75.508 & 0.000 & + & + & + & + & + & \\
\hline Slope & Slope & $\%$ & 32.538 & 0.000 & + & + & + & + & + & \\
\hline Io & Ombrothermic index & & 75.508 & 0.000 & + & + & + & + & + & \\
\hline It & Thermicity index & & 75.509 & 0.000 & + & + & + & + & + & \\
\hline
\end{tabular}

Label used in graphical representations, measurement unit and ANOVA of 32 environmental variables for four groups and results for multiple comparisons for all pairs with LSD (least significant difference) procedure. With “+” pairs of groups different for a $95 \%$ confidence

Our survey included 32 environmental variables (Tab. 1 shows the label and the measurement units for each variable), which were incorporated as thematic layers into a geographical information system (ArcGis 9.3).

\section{Data analysis methods}

With the data collected from 28 plots, we analysed the relationships between environmental variables and plant species abundance by means of two different matrices. The Kolmogorov-Smirnov test revealed that the ecological response of plant species is not unimodal. Therefore we opted for a redundancy analysis (RDA), which is a direct gradient analysis that assumes a linear response of species. The numerical analysis was performed in Canoco v.4.02 (ter Braak and Smilauer, 1998).

A total of 51 vascular plant species were recorded. The full names and labels of these species are listed in Tab. 2. In the RDA analysis the original species abundance data were logarithmically transformed as follows: $x^{\prime}=\log (x+1)$.

The Monte Carlo test was used to select the ten most significant environmental variables. By this procedure, redundant variables could be individuated. In addition, a cluster analysis was implemented to group the species according to their scores on the four axes of the RDA. Through this combinatorial technique, we could integrate the information from the RDA four-dimensional space into the graphic representation of the two first axes.

This cluster analysis was made by means of the squared Euclidean distance and the Ward method as grouping techniques. Finally, an ANOVA analysis of 32 environmental variables for all groups of species and post hoc multiple comparisons for all pairs (LSD method) were made. 


\section{Results and discussion}

\section{Plant ordination}

The RDA and complementary cluster analysis produced four ecologically distinct groups of species (A, B, $\mathrm{C}$ and $\mathrm{D})$. These groups present significant differences $(p<0.05)$ for all the environmental variables involved, except for OC. Most of these variables can be used to discriminate between any possible pair of groups. At all events, $\mathrm{OC}$ is significant enough to discriminate between the pair C/D (Tab. 1)

The relation species/environmental variables accounts for $73.3 \%$ of the variance conveyed by the four ordination axes (Fig. 2). The eigenvalues of the first two axes of the RDA accounts for $50.0 \%$ of that relation. As for the variance percentage accounted for by the environmental variables, the ten most significant ones in decreasing order are: Clay (19\%), Sand (7\%), K (6\%), OC (5\%), Slope (5\%), Io (5\%), N (4\%), CEC (4\%), CO3 (3\%) and Hsat (3\%).

Axis 1, which accounts for $34.6 \%$ of the total variance observed, attests to an intense environmental gradient in the direction of the river flow. The most noticeable sign of this gradient is the different soil textures observed: in the positive part of the axis the high percentages of Sand heavily contrast with the high contents of Clay in the negative part. Likewise, in the positive part of axis 1 we find high Io and Slope values with low $\mathrm{CEC}, \mathrm{CO}_{3}$ and $\mathrm{K}$ values. This fact clearly reveals that, as the river flows downstream, the size of the particles which are deposited and the ombrothermic index decrease as the slope decreases, and the CEC, $\mathrm{K}$ and $\mathrm{CO}_{3}$ values increase dramatically.

Axis 2, which accounts for $15.4 \%$ of the variance, is related to Hsat, Io and Slope. It provides better discrimination between the pair A/C according to the Sand content and Io, and between the pair B/D according to Hsat.

One group of species appears in each of the four quadrants of the ordination diagram (Fig. 2). The species groups are positioned along the strong gradient revealed by the whole set of variables under study along the whole course of the river. Groups A and D appear at the ends of this gradient, while $\mathrm{B}$ and $\mathrm{C}$ appear as transitional groups. Although there is some distributional overlapping between some species belonging to groups $\mathrm{A}$ and $\mathrm{B}$, on the one hand, and species belonging to groups $\mathrm{C}$ and $\mathrm{D}$, on the

Tab. 2. Species present in the samples with full names and labels for the graphical representation

\begin{tabular}{|c|c|c|c|}
\hline Label & Name & Label & Name \\
\hline AEL_LIT & Aeluropus littoralis (Gouan) Parl. & POL_AVI & Polygonum aviculare $\mathrm{L}$. \\
\hline ALN_GLU & Alnus glutinosa (L.) Gaertner & POL_EQU & Polygonum equisetiforme Sm. \\
\hline ART_MAC & $\begin{array}{c}\text { Arthrocnemum macrostachyum (Moric.) } \\
\text { Moris in Moris \& Delponte }\end{array}$ & POL_MAR & Polypogon maritimus Willd. subsp. maritimus \\
\hline ARU_DON & Arundo donax L. & POP_ALB & Populus alba L. \\
\hline CAR_ACU & Carex acuta L. & POP_NIG & Populus nigra L. \\
\hline CRE_CRE & Cressa cretica L. & RAN_TRI & Ranunculus trilobus Desf. \\
\hline CRY_ACU & Crypsis aculeata (L.) Aiton & RUB_ULM & Rubus ulmifolius Schott \\
\hline CYP_LON & Cyperus longus $\mathrm{L}$. & SAL_ALB & Salix alba $\mathrm{L}$ \\
\hline DAM_BOU & $\begin{array}{l}\text { Damasonium alisma subsp. } \\
\text { bourgaei (Cosson) Maire }\end{array}$ & SAL_NEO & Salix neotricha Goerz \\
\hline EQU_TEL & Equisetum telmateia Ehrh. & SAL_PED & Salix pedicellata Desf. \\
\hline FRA_LAE & Frankenia laevis L. & SAL_SAL & Salix salviifolia Brot. \\
\hline FRA_ANG & Fraxinus angustifolia Vahl subsp. angustifolia & SAR_PER & $\begin{array}{l}\text { Sarcocornia perennis subsp. } \\
\text { alpini (Lag.) Castrov. }\end{array}$ \\
\hline HAL_POR & Halimione portulacoides (L.) Aellen & SCH_NIG & Schoenus nigricans $\mathrm{L}$. \\
\hline INU_CRI & Inula crithmoides $\mathrm{L}$. & SCI_HOL & Scirpus holoschoenus L. \\
\hline JUN_ACU & Juncus acutus L. & SCI_LIT & Scirpus litoralis Schradeder \\
\hline JUN_SUB & Juncus subulatus Forsskål & SCI_COM & Scirpus maritimus subsp. compactus Hoffm. \\
\hline LYT_SAL & Lythrum salicaria $\mathrm{L}$. & SEC_TIN & Securinega tinctoria (L.) Rothm. \\
\hline LYT_TRI & Lythrum tribracteatum Spreng. & SPA_DEN & Spartina densiflora Brongn. \\
\hline MEN_SUA & Mentha suaveolens Ehrh. & SUA_SPL & Suaeda splendens (Pourr.) Gren. \& Godr. \\
\hline MYR_COM & Myrtus communis $\mathrm{L}$. & SUA_VER & Suaeda vera Forssk. ex J.F. Gmel. \\
\hline NER_OLE & Nerium oleander L. & TAM_AFR & Tamarix africana Poir. \\
\hline OEN_CRO & Oenanthe crocata L. & TAM_MAS & Tamarix mascatensis Bunge \\
\hline PAR_INC & Parapholis incurva (L.) C.E.Hubb. & TRI_RES & Trifolium resupinatum $\mathrm{L}$. \\
\hline PAR_PYC & Parapholis pycnantha (Hack.) C.E.Hubb. & TYP_DOM & Typha dominguensis (Pers.) Steudel \\
\hline PAS_VAG & Paspalum vaginatum Swartz & ULM_MIN & Ulmus minor Mill. \\
\hline PHR_AUS & Phragmites australis (Cav.) Trin. ex Steud. & & \\
\hline
\end{tabular}




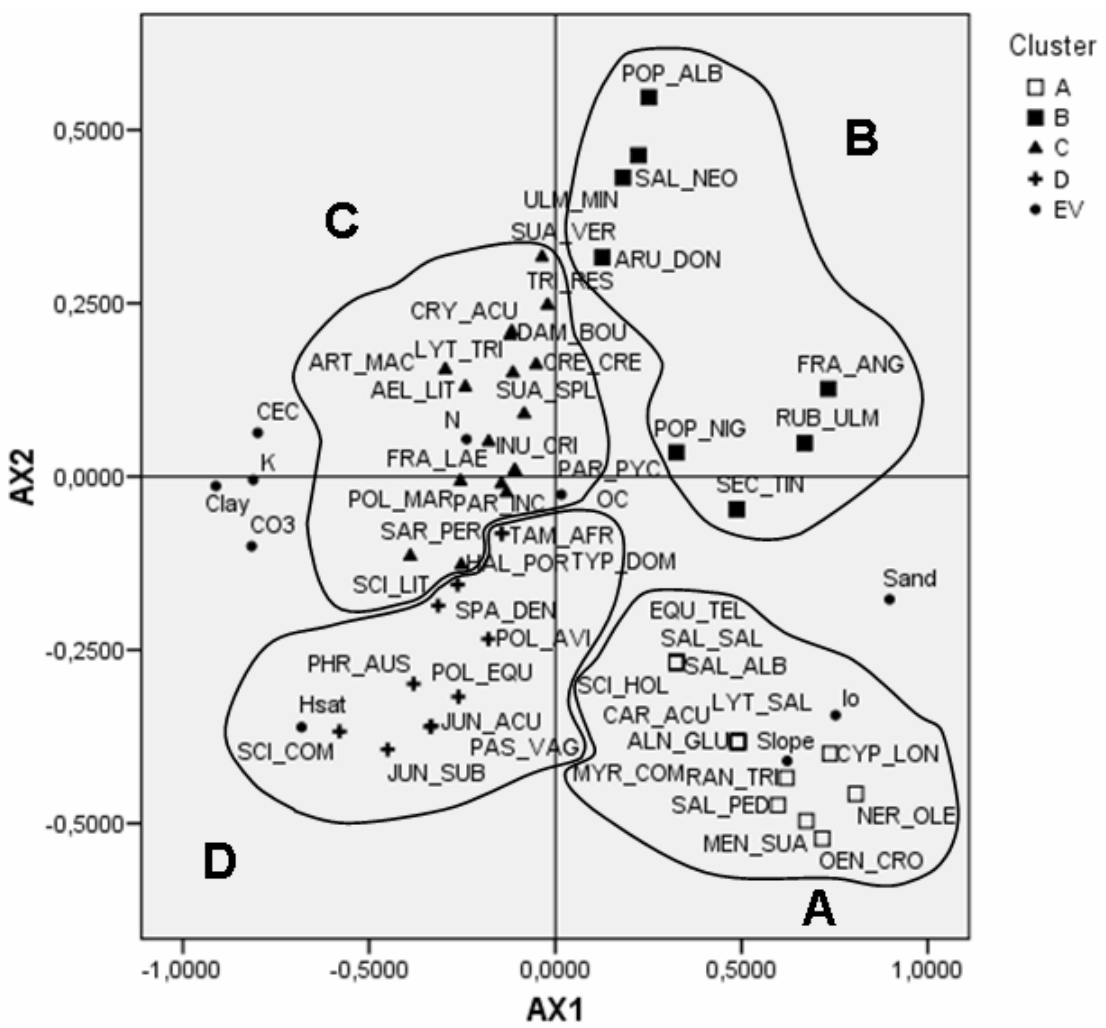

Fig. 2. Ordination of plant species in the space of the first two RDA axes. Species have been ascribed to one of four groups, according to cluster analysis output. ( $\square, \mathbf{\square}, \boldsymbol{\Delta},+$ species group; • environmental variables). Species abbreviations as in Tab. 2

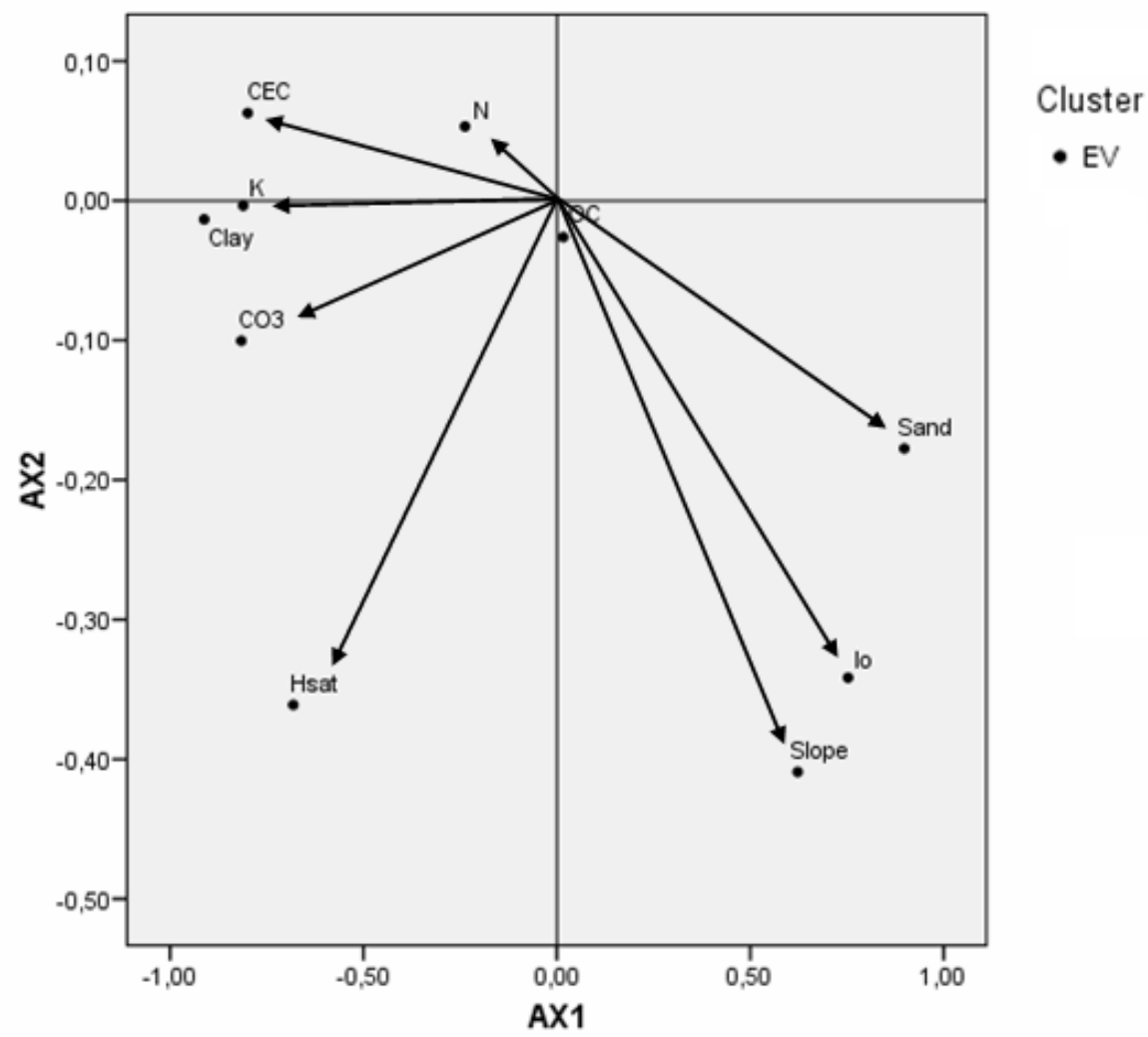

Fig. 3. Vector representation of the most important environmental variables in the ordination space of the first two RDA axes 
other, no overlapping whatsoever has been found between blocks $\mathrm{A} / \mathrm{B}$ and $\mathrm{C} / \mathrm{D}$ (Fig. 4).

Groups A and B are more closely interrelated with each other than they are with groups $\mathrm{C}$ and $\mathrm{D}$. The species of group $\mathrm{A}$ align themselves with higher Sand and Io values (Fig. 2 and 3). None of the ten variables selected by the $\mathrm{RDA}$ are located in the quadrant of group C. This is due to the transitional character of this zone. Group $\mathrm{C}$ is related to high Clay, CEC and K values. Group D is clearly aligned with high $\mathrm{Hsat}$ values.

\section{Gradient analysis}

The first two RDA axes (Fig. 2 and 3) reveal the change in level of the physical, chemical and bioclimatic parameters along the Guadiamar River watercourse.

The size of the sediment particles decreases in the lower reaches of the river in relation to the geomorphological profile of the river course (Beauchamp et al., 2007; Beauchamp and Stromberg, 2008; Diju and Thamban, 2006).

A bioclimatic gradient with the highest ombrothermic index values (aligned with Alt and Sand) in contrast to those of the thermicity index can also be found. This means that thermicity increases and the ratio precipitation/temperature decreases as the river flows downstream.

It was also found a strong chemical gradient with high values of CEC, Ca, Mg, Na, K, V, Caex, Mgex, Naex, Kex, $\mathrm{pH}, \mathrm{pH} \_\mathrm{KCl}$ and $\mathrm{EC}$ in the negative quadrant of axis 1 and the positive quadrant of axis 2 . In this respect, only $\mathrm{CN}$ values are higher in the opposite quadrant.

Heavily aligned with axis 1 , these three instances of overlapping are the cause of the highly contrasting zonation of vegetation types along the course of the river (Fig. 4).

As crossed gradients we found high values of $\mathrm{P}$ and CS in the positive quadrant of both axes, which indicates a greater man-induced impact (agriculture, waste spills, etc.) on the middle reaches of the river, where soil texture is also transitionally medium-size. By contrast, in the negative quadrant of both axes we found high values of Hsat (in relation to a high percentage of Silt), $\mathrm{CO}_{3} \mathrm{ex}$ and $\mathrm{HCO}-$ ${ }_{3} \mathrm{ex}$. These two variables reveal that the stagnant water of the marshland areas which are flooded for longer periods of time (where species of group D occur) is of continental origin, whereas the salts concentrated on the seasonal marshland soils have a strong salt water component. This still remaining impact of the sea on the soils is undoubt- edly a vestige of a time when the river dynamics were more natural and dependent on sea tides. In more recent times the construction of roads and farming practices put an end to those dynamics.

\section{Analysis of species groups}

Plant species are arranged into four groups, according to the correlation coefficients with regard to each canonical axis. Consequently, each group of species corresponds to one of four clear-cut habitats that can be found along the course of the river: enclosed, deep-carved gullies (group A), open river valley with low slopes (group B), high or seasonal marshland (group C) and low or permanent marshland (group D) (Fig. 4).

Group A occurs only in the upper reaches of the river, where the river flows through deep gullies and the superficial water stream never runs dry. This mountainous stretch presents terrains with steep slopes, with soils rich in sand and an ombrothermic index (Io) at the highest levels.

The group grows on dystric soils, poor in exchange cations and with an average $\mathrm{pH}$ record under 7. All this is not only due to a remarkably high sand content and a precipitation rate that encourages soil denudation, but also to the short supply of bases in the materials on which the soils develop. The extremely low equivalent calcium carbonate content depends heavily on these materials.

The alder tree (Alnus glutinosa) is a salient species of this reach of the river and an effective bioindicator of this group. It is ideally adapted to this kind of environment (Díaz et al., 1987; Naqinezhad, 2008). In these alder tree woods $\mathrm{pH}$ is 6.91 (measurements in water) and $\mathrm{CN}$ is 19.5. These values correspond to the eutrophic type, as suggested by Prieditis (1997).

The species of group B can be found both in the upper and middle reaches, always in combination with open river course environments, gentle slopes and areas where the superficial water stream may dry up during prolonged, very dry summers. These species present medium values for all the variables involved, except for Hsat, which shows low values here as a result of the still high sand concentration in the soil. The records of Slope, Io, Sand, Clay, CEC and $\mathrm{Hsat}$ for this group describe a flat habitat, with average precipitation rates, a dominance of sand over clay, poor salinity and low water saturation in soil. The recorded plant dispersion among the species of the group reveals a certain

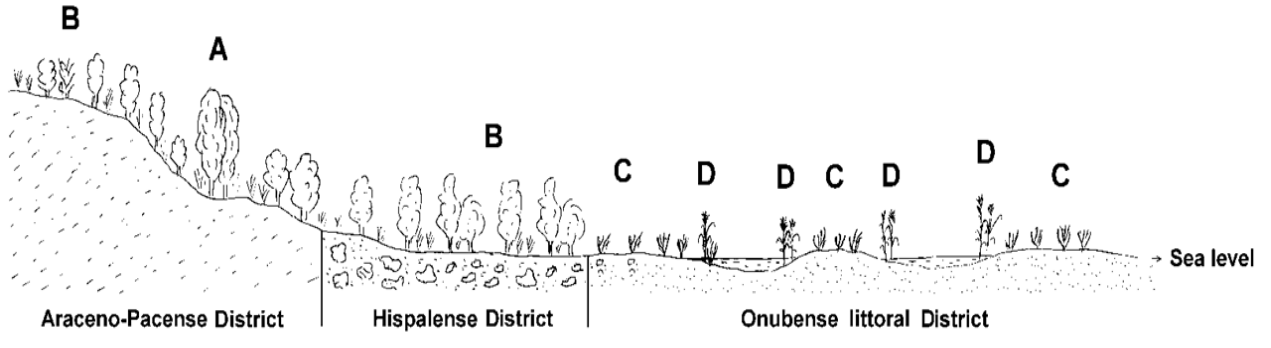

Fig. 4. Distribution scheme of the groups of species along the Guadiamar River 
28

degree of ecological flexibility, in line with transitional environments.

The species of group B prefer eutric soil, richer in bases, higher $\mathrm{pH}$ records and higher contents of equivalent calcium carbonate than group A species. The tolerance ranges of $\mathrm{B}$ species are, in general, wider than those of group $\mathrm{A}$, whose species assume an extreme position. It is worth noting the preference of these plants for soils with a more balanced texture and better water retentive capacities.

The most significant bioindicators in this group are Populus alba, P. nigra and Ulmus minor. The assemblages of Rubus ulmifolius and Arundo donax are frequent in this reach of the river as usually happens in riparian areas where human intervention has taken place (Beerling, 1991; Corbacho et al., 2003; Nilsson et al., 1989). Ulmus minor is an element of wet flood plains and grows best on fertile alluvial soils in marshy places (Browicz, 1982).

Groups $C$ and $D$ are found in the lowest reach of the river, always in flat, floodable zones, in marshland-like environments that share identical climatic conditions. The soils occupied by species in these two groups are highly basic, salty and, in general, heavy, which usually impedes water drainage and the washing out of salts. Plants alternate according to microtopography. Thus, the species of group $\mathrm{C}$ tend to occur in higher zones subject to severe summer droughts and locally known as "vetas", while the species in group D tend to grow in microdepressions, waterlogged for long periods of time, locally known as "lucios". A zonation of species distribution with respect to elevation is one of the characteristic features of tidal salt marshes (Adam, 1990; Davy and Costa, 1992) and has been interpreted as an expression of past or present succession processes associated with sedimentary accretion (Davy, 2000).

The results obtained for group $\mathrm{C}$ confirm that the soils are very clayey (Clay $60.44 \%$, Sand $2.4 \%$ ), with a correspondingly high Hsat $(80.09 \%)$, and a high water storage capacity, both values in field capacity (H33), particularly, at wilting point (H1500). Not surprisingly, the amount of water available for plants is not excessively high.

Among the bioindicators of group C, Arthrocnemum macrostachyum stands out as a species well adapted to the most extreme habitats. It endures the highest levels of soil salinity ( 5.21 to $55.5 \mathrm{dS} \cdot \mathrm{m}^{-1}$ ) and the most severe seasonal fluctuations (Gómez Mercado et al., 2012). As for Sarcocornia perennis subsp. alpini, it can tolerate similar salt concentrations ( 9.73 to $55.5 \mathrm{dS} \cdot \mathrm{m}^{-1}$ ), but its optimum occurs on soils subject to less dramatic seasonal changes. Álvarez Rogel et al. (2001) already recorded this behaviour in A. macrostachyum and S. fruticosa.

Group D is found in low or permanent marshland with prolonged flooding and where seasonal drought is short or non-existent. Hsat values are the highest here. The species of this group grow on soils of a clayey texture, where the content of exchangeable ions is very high. EC presents an average value of $12.51 \mathrm{dS} \cdot \mathrm{m}^{-1}$, i.e., much lower than that of group C. However, this group of species can still be considered as definitely halophilous plants.

As happens in other saltmarshes in the SE of the Iberian Peninsula (Álvarez Rogel et al., 2001), in this environment the species of rushes (Juncus acutus) are dominant. The EC values of the samples where this species occurs ranged from 9.73 to $11.07 \mathrm{dS} \cdot \mathrm{m}^{-1}$.The best bioindicators in this group are Phragmites australis, Scirpus maritimus subsp. compactus, Scirpus litoralis and Typha dominguensis.

The reed (Phragmites australis) is a moderately halophilous species recorded by Cizkova et al. (2001) with electrical conductivity values ranging from 2.52 to 5.03 $\mathrm{d} S \cdot \mathrm{m}^{-1}$. We ourselves found the species in sites where the salinity records are higher, ranging from 6.51 to 37.9 $\mathrm{d} S \cdot \mathrm{m}^{-1}$.

Watt et al. (2007) reported that Scirpus maritimus (varietal type unknown) showed wide ecological amplitude and that its distribution was not limited by soil salinity over the range found $\left(0.57-4.1 \mathrm{dS} \cdot \mathrm{m}^{-1}\right)$. Its natural habitat is on the edge of brackish or saline pools with large variations in water chemistry, particularly conductivity (Kadlec and Smith, 1989; Lieffers and Shaym, 1982). In our samples, Scirpus maritumus var. compactus shows an EC range between 13.79 and $55.5 \mathrm{dS} \cdot \mathrm{m}^{-1}$, whereas Scipus littoralis varies between 6.33 and $7.06 \mathrm{dS} \cdot \mathrm{m}^{-1}$.

Spartina densiflora is considered an allochthonous species and an aggressive invader, capable of acting as salt marsh pioneers and persisting in more mature communities (Costa et al., 2003). In our zone, the plant presents an EC tolerance range varying from 19.49 to $37.9 \mathrm{dS} \cdot \mathrm{m}^{-1}$.

Besides the clear difference in the total Na content, the contents of exchangeable ions of the adsorption complex of the soil also show clear differences between groups $\mathrm{C}$ and $\mathrm{D}$.

The clear-cut spatial separation between groups $\mathrm{A} / \mathrm{B}$, on the one hand, and groups $\mathrm{C} / \mathrm{D}$, on the other, testify to a discriminative complex of ecological factors for the distribution of these plant species. There is no doubt that the main ecological factor associated with such a sharp differentiation is salinity. The threshold is about $2.28 \mathrm{dS} \cdot \mathrm{m}^{-1}$ EC, which is the distributional limit of wide-ranging, nonhalophilous species, such as Fraxinus angustifolia, Populus alba and Ulmus minor.

As commented by Sieben and Reineke (2008) and Álvarez Rogel et al. (2001), further general research on species and plant communities from different backgrounds is required to support efficient future restoration programmes on the basis of general rather than local patterns. This strategy will also allow efficient use of plant species as bioindicators and could save an enormous amount of effort and costs when designing suitable restoration plans for wetlands.

\section{Acknowledgements}

This research is part of the report of the investigation project "Composition, structure, restoration and pres- 
ervation of the cormophyte vegetal communities of the Guadiamar River basin" (PICORVE, convenio nr. 14), financed by the Oficina Técnica del Corredor Verde del Río Guadiamar, Consejería de Medio Ambiente, Junta de Andalucía. Resources from the project P06-RNM-02286 (Call for Projects of Excellence 2006 of the Junta de Andalucía) have also been used.

\section{References}

Adam P (1990). Saltmarsh Ecology. Cambridge University Press. Cambridge, UK.

Álvarez Rogel J, Ortiz Silla R, Alcaraz Ariza F (2001). The application of the FAO and US soil taxonomy systems to saline soils in relation to halophytic vegetation in SE Spain. Catena 45:73-84.

Bartels JM (Ed.) (1996). Methods of Soils Analysis. Part 3. Chemical Methods. SSSA Book Series 5, Madison, 1390 p.

Beauchamp VB, Stromberg JC, Stutz JC (2007). Flow regulation has minimal influence on mycorrhizal fungi of a semiarid floodplain ecosystem despite changes in hydrology, soils and vegetation. J Arid Environ 68:188-205.

Beauchamp VB, Stromberg JC (2008). Changes to herbaceous plant communities on a regulated desert river. River Res Appl 24:754-770.

Beerling DJ (1991). The effect of riparian land use on the occurrence and abundance of Japanese knotweed Reynoufria japonica on selected rivers in South Wales. Biol Conserv 55:329-337.

Böer B (1996). Plants as soil indicators along the Saudi coast of the Arabian Gulf. J Arid Environ 33(4):417-423.

Braun-Blanquet J (1964). Pflanzensoziologie. Grundzüge der Vegetationskunde. Ed. 3. Springer Verlag, Wien, 865 p.

Bremmer JM (1996). Nitrogen-Total, 1085-1121 p. In: Bigham JM (Ed.). Methods of Soil Analysis. Part 3. Chemical Methods. Number 5 in the SSSA Book Series, Soil Science Society of America, Inc. American Society of Agronomy, Inc. Madison, Wisconsin.

Browicz K (1982). Chorology of Trees and Shrubs in Southwest Asia and Adjacent Regions, vol. 1. Polish. Scientific Publisher, $172 \mathrm{p}$.

Castillo JM, Fernández Baco L, Castellanos EM, Luque CJ, Figueroa ME, Davy AJ (2000). Lower limits of Spartina densiflora and $S$. maritima in a Mediterranean salt marsh determined by different ecophysiological tolerances. J Ecol 88:801-812.

Ceschin S, Zuccarello V, Caneva G (2010). Role of macrophyte communities as bioindicators of water quality: Application on the Tiber River basin (Italy). Plant Biosyst 144(3):528536.

Cizkova H, Pechar L, Stepan H, Kvet J, Bauer V, Edwards K (2001). Chemical characteristics of soils and pore waters of three wetland sites dominated by Phragmites australis: relation to vegetation composition and reed performance.
Aquat Bot 69:235-249.

Corbacho C, Sánchez JM, Costillo E (2003). Patterns of structural complexity and human disturbance of riparian vegetation in agricultural landscapes of a Mediterranean area. Agric Ecosys Environ 95:495-507.

Costa DSB, Marangoni JC, Azevedo G (2003). Plant zonation in irregularly flooded salt marshes: relative importance of stress tolerance and biological interactions. J Ecol 91:951965.

Davy AJ, Costa CSB (1992). Development and organization of Saltmarsh communities, 157-178 p. In: Seeliger U (Ed.). Coastal plant communities of Latin America. Academic Press Inc., San Diego.

Davy AJ (2000). Development and structure of salt marshes: community patterns in time and space, 137-156 p. In: Weinstein M, Kreeger D (Eds.). Concepts and controversies in tidal marsh ecology, Kluwer Publishing, Dordrecht.

Díaz E, Puente E, Pérez C, García R (1987). Síntesis de las macroseries riparias mediterráneas de la provincia de León. V Jornadas de Fitosociología. Vegetación de riberas de agua dulce. Universidad de la Laguna, 249-265 p.

Díaz-Maroto IJ, Vila-Lameiro P (2008). Chemical properties and macronutrients of oak soils in northwest Spain. Commun Soil Sci Plant Anal 39:1416-1435.

Diju S, Thamban M (2006). Clay mineral and textural variations in the sediments of Chandagiri River, estuary and shallow marine realms off Kasaragod, Kerala. J Geol Soc India 67:189-196.

Galuszka A (2000). The Chemistry of Soils, Rocks and Plant Bioindicators in Three Ecosystems of the Holy Cross Mountains, Poland. Environ Monit Assessm1 10(1-3):55-70.

Glenz C, Schlaepfer R, Iorgulescu I, Kienast F (2006). Flooding tolerance of Central European tree and shrub species. For Ecol Manage 235:1-13.

Gómez Mercado F, del Moral F, Giménez Luque E, de Haro S (2012). Salinity Tolerance of the Hygrophilous Plant Species in the Wetlands of the South of the Iberian Peninsula. Not Bot Horti Agrobo 40(1):18-28.

Gómez Mercado F, Giménez Luque E, Delgado IC, de Haro S, del Moral F (2009). Estimación de los rangos de tolerancia a los factores ambientales de diversas especies mediterráneas de interés ecológico-forestal. Lazaroa 30:147-161.

Gómez Mercado F, Giménez Luque E, López Carrique E, de Haro S, del Moral F (2010). Ecological behaviour of some Mediterranean plant species: scientific grounds for restoration. Acta Bot Gall 157(2):329-340.

Gómez Mercado F, Navarro J, Giménez Luque E, Delgado IC, de Haro S, del Moral F (2007). Valoración naturalística del Corredor Verde del Río Guadiamar (Andalucía, España). Lagascalia 27:7-22.

Hagen-Thorn A, Callesen I, Armolaitis K, Nihlgård B (2004). The impact of six European tree species on the chemistry of 
30 mineral topsoil in forest plantations of former agricultural land. For Ecol Manage 195:373-384.

Kadlec JA, Smith LM (1989). The Great Basin Marshes, 451 474 p. In: Smith LM, Pederson RL, Kaminski RM (Eds.). Habitat management for migrating and wintering waterfowl in North America. Texas Tech University Press, Lubbock.

Klumpp A, Klumpp G (1994). Plants as bioindicators of air pollution at the Serra do Mar near the industrial complex of Cubatão, Brazil. Environ Pollution 85(1):109-116.

Klute A (Ed.) (1986). Methods of Soil Analysis. Part 1. Physical and Mineralogical Methods. Second Edition, SSSA Book Series nr. 9, Madison, $1188 \mathrm{p}$.

Konisky RA, Burdick DM (2004). Effects of stressors on invasive and halophytic plants of New England salt marshes: A framework for predicting response to tidal restoration. Wetlands 24:434-447.

Lee BA, Kwon KG, Kim JG (2005). The relationship of vegetation and environmental factors in Wangsuk stream and Gwarim reservoir: I. Water environments. Korean J Ecol 28:365-374.

Lieffers VJ, Shaym JM (1982). Distribution and variation in growth of Scirpus maritimus var.paludosus on the Canadian praries. Can J Bot 60:1938-1949.

Lu T, Ma KM, Zhang WH, Fu BJ (2006). Differential responses of shrubs and herbs present at the Upper Minjiang River basin (Tibetan Plateau) to several soil variables. J Arid Environ 67:373-390.

Migaszewski ZM, Galuszka A, Swiercz A, Kucharzyk J (2001). Element Concentrations in Soils and Plant Bioindicators in Selected Habitats of the Holy Cross Mountains, Poland. Water, Air Soil Pollution 129(1-4):369-386.

Mitsch WJ, Gosselink JG (2000). Wetlands. 3rd edn. Wiley, New Cork.

Montes del Olmo C, Rendón Martos M, Varela Báez L, Cappa Linares MJ (2007). Manual de restauración de los humedales mediterráneos. Consejería de Medio Ambiente. Junta de Andalucía.

Naqinezhad A, Hamzeh'ee B, Attar F (2008). Vegetationenvironment relationships in the alderwood communities of Caspian lowlands, N. Iran (toward an ecological classification). Flora 203:567-577.

Navarro RM, Lara A, Blanco P, Calzado C, López J, Fernández A, Guzmán JR, Sánchez R (2006). Aproximación a la definición del hábitat fisiográfico del Abies pinsapo Boiss. en Andalucía. Invest Agrar: Sist Recur. For Fuera de Serie: 137-152.

Nilsson C, Grelsson G, Johansson M, Sperens U (1989). Patterns of plant species richness along riverbanks. Ecology 70:77-84.

Olsen SR, Cole CV, Watanabe FS, Dean LA (1954). Estimation of available phosphorus on soils by extraction with sodium bicarbonate. USDA circ. 939. USDA, Washington, DC.
Prieditis N (1997). Alnus glutinosa- dominated wetland forests of the Baltic Region: community structure, syntaxonomy and conservation. Plant Ecol 129:49-94.

Richards LA (1954). Diagnosis and improvement of saline and alkali soils. Handbook 60. U.S. Salinity Laboratory, USDA. Washington.

Rivas Martínez S, Asensi A, Díez-Garretas B, Molero Mesa J, Valle F (1997). Biogeographical synthesis of Andalusia (southern Spain). J Biogeo 24:915-928.

Rivas Martínez S, Loidi J (1999). Bioclimatology of the Iberian Peninsula. In: Rivas Martínez $S$ et al., Iter Ibericum A.D. MIM. (Excursus geobotanicus per Hispaniam et Lusitaniam, ante XLII Symposium Societatis Internationalis Scientiae Vegetationis Bilbao mense Iulio celebrandum dicti Anni). Itinera Geobotanica 13:41-47.

Robach F, Thiébaut G, Trémolières M, Muller S (1996). A reference system for continental running waters: plant communities as bioindicators of increasing eutrophication in alkaline and acidic waters in north-east France. Hydrobiologia 340(1-3):67-76

Rubio A, Castillo JM, Luque CJ, Figueroa ME (2003). Influence of salinity on germination and seeds viability of two primary colonizers of Mediterranean salt pans. J Arid Environ 53:145-154.

Rubio A, Escudero A, Gandullo JM (1997). Sweet chestnut silviculture in an ecological extreme of its range in the west of Spain (Extremadura). Ann Sci For 54:577-696.

Sieben EJJ, Reinecke MK (2008). Description of reference conditions for restoration projects of riparian vegetation from the species-rich fynbos biome. S Afr J Bot 74:401411.

Soil Conservation Service (1972). Soil survey laboratory methods and procedures for collecting samples. USDA. Washington.

Ter Braak CJF, Smilauer P (1998). CANOCO reference manual and user's guide to canoco for windows: Software for canonical community ordination (version 4). Microcomputer Power, Ithaca, NY, $352 \mathrm{p}$.

Thuiller W, Vayreda J, Pino J, Sabate S, Lavorel S, Gracia C (2003). Large-scale environmental correlates of forest tree distributions in Catalonia (NE Spain). Glob Ecol Biogeogr 12:313-325.

van der Maarel E (1979). Transformation of cover-abundance values in phytosociology and its effects on community similarity. Vegetatio 39(2):97-114.

Watt SCL, García-Berthou E, Vilar L (2007). The influence of water level and salinity on plant assemblages of a seasonally flooded Mediterranean wetland. Plant Ecol 189:71-85.

Zuccarini P, Kampuš S (2011). Two aquatic macrophytes as bioindicators for medium-high copper concentrations in freshwater. Plant Biosyst 145(2):503-506 